\title{
Cooperative Method of Talking Chips Types in Character Education to Improve Discipline of SMP Students
}

\author{
Novilia Mita Sari \\ Students of Sciences / Education of Mathematics and ciences, FKIP, University of Jember, Indonesia
}

\begin{abstract}
The purpose of this study is to determine the cooperative method of talking chips type in character education for junior high school students. Data is taken from trusted literature such as books and journals. The method used is a match (looking for a partner), 2. Think Fair-Share (thinkingpairing), 3. Talking chips, 4. roundtable. The results will be expected later for junior high school students when the learning process and student learning are more active, disciplined, organized and evenly distributed.
\end{abstract}

Keywords: method, students, character education, discipline

\section{PENDAHULUAN}

Pendidikan nasional berdasarkan UUD 1945 bab II pasal 3 menjelaskan bahwa pendidikan memiliki fungsi mengembangkan kemampuan serta meningkatkan mutu kehidupan dan martabat manusia dalam rangka mencerdaskan kehidupan bangsa dan bertujuan berkembangnya kemampuan peserta didik agar menjadi manusia beriman dan bertaqwa kepada Tuhan Yang Maha Esa, berakhlak mulia, sehat, berilmu, cakap, kreatif, mandiri dan menjadi warga negara yang demokratis serta bertanggung jawab (DEPDIKNAS.2006:6).

Model pembelajaran yang digunakan dalam pembelajaran harus relevan dan mendukung tercapainya tujuan pembelajaran. Ketepatan dalam menggunakan metode atau model mengajar yang dilakukan oleh guru dapat membangkitkan motivasi dan juga minat siswa terhadap mata pelajaran yag diberikan oleh guru dan juga terhadap proses dan hasil belajar siswa (Karyana.2013:9).

Didalam bidang pendidikan sangat banyak bidang-bidang ilmu yang terus berkembang dan salah satunya adalah Ilmu kimia. Ilmu kimia merupakan salah satu cabang Ilmu Pengetahuan Alam (IPA) yang merupakan bidang studi yang biasanya dipelajari pada tingkat SMA/MA. Pelajaran kimia pada hakekatnya adalah pelajaran yang sangat erat hubungannya dalam kehidupan sehari-hari dan telah memberikan banyak manfaat bagi manusia.
Pembelajaran

Kooperatif

Tipe Talking ChipsTalking adalah sebuah kata yang diambil dari bahasa inggris yang berarti berbicara, sedangkan chips yang berarti kartu. Jadi arti talking chips adalah kartu untuk berbicara (Enteng.2013:55).

Sedangkan talking chips dalam pembelajarankooperatif yaitu pembelajaran yang dilakukan dalam kelompok kecil yang terdiri atas 4-5 orang, masing-masing anggota kelompok membawa sejumlah kartu yang berfungsi untuk menandai apabila mereka telah berpendapat dengan memasukkan kartu tersebut ke atas meja. Model pembelajarantalking chips atau kancing gemerincing merupakan salah satu model pembelajaran yang menggunakan metode pembelajaran kooperatif (sudjana.2002: 43).

Berdasarkan prosedur pembelajaran pelaksanaanya (Bassham.2011: 55)., membedakan pembelajaran kooperatif dalam beberapa tipe, yaitu make a match (mencari pasangan), Think-Fair-Share (berpikir - berpasangan - berbagi), bertukar pasangan, berkirim salam dan soal, numbered heads together (kepala bernomor), two stay two stray (dua tamu dua tinggal), talkingchips (kartu berbicara), roundtable (meja bundar), inside-outside-circle (lingkaran besar lingkaran kecil), paired storytelling (berbicara berpasangan), three steps interview (tiga tahap wawancara).

Pembelajar kooperatif tipe talking $\mathrm{c}$ hips pertama kali dikembangkan oleh Spencer Kagan pada tahun 1992. Dalam kegiatan talking chips, masing-masing 
anggota kelompok mendapat kesempatan untuk memberikan kontruksi mereka dan mendengarkan pandangan dan pemikiran anggota yang lain. Keunggulan lain dari teknik ini adalah untuk mengatasi hambatan pemerataan kesempatan yang sering mewarnai kerja kelompok. Sebagaimana dinyatakan Masitoh dan Laksmi Dewi dalam bukunya Strategi Pembelajar (2009:244) model

pembelajaran talking chips merupakan mod el pemelajaran kancing gemerincing yang dikembangkan oleh Spender Kagan (Bassham.2011: 58).

Dalam

pelaksanaan talking chips setiap anggota kelompok diberi sejumlah kartu atau "chips" (biasanya dua sampai tiga kartu). Setiap kali salah seorang anggota kelompok menyampaikan pendapat dalam diskusi, ia harus meletakan satu kartunya ditengah kelompok. Setiap anggota diperkenankan menambah pendapatnya sampai semua kartu yang dimilikinya habis. Jika kartu yang dimilikinya habis, ia tidak boleh berbicara lagi sampai semua anggota kelomoknya juga menghabiskan semua kartu mereka. Jika semua kartu telah habis, sedangkan tugas belum selesai, kelompok boleh mengambil kesempatan untuk membagi-bagi kartu lagi dan diskusi dapat diteruskan kembali (Sudjana. 2002: 47).

Menurut Kamus Besar Bahasa Indonesia (KBBI) hal 623, Karakter adalah sifat-sifat kejiwaan, perilaku atau budi pekerti yang membedakan seseorang dari yang lain. Berkarakter berarti memiliki karakter, mempunyai kepribadian dan berwatak. Individu yang berkarakter baik atau unggul adalah seseorang yang berusaha melakukan hal-hal yang terbaik terhadap Tuhan Yang Maha Esa, dirinya, sesama, lingkungan, bangsa dan negara pada umumnya dengan mengoptimalkan potensi (pengetahuan) dirinya dan disertai dengan kesadaran, emosi dan motivasinya (perasaannya) (Aqila.2011: 3).

Karakter dapat dimaknai sebagai nilai dasar yang membangun pribadi seseorang, terbentuk baik karena pengaruh hereditas maupun pengaruh lingkungan, yang membedakannya dengan orang lain, serta diwujudka dalam sikap dan perilakunya dalam kehidupan sehari-hari. Pendidikan Karakter adalah usaha sadar dan terencana dalam menyiapkan peserta didik untuk mengenal, memahami, dan menerapkan dalam kehidupan sehari hari dengan melalui kegiatan bimbingan, pengajaran, latihan, serta penggunaan pengalaman (Djamarah.2000: 30-31).

Siswa sebagai peserta didik, terutama dalam membntuk dan membina karakternya. Proses belajar mengajar Pendidikan Karakter dengan penekanan karakter dapat bermakna dan berdaya guna dalam menciptakan suasana belajar yang merangsang prestasi belajar, meningkatkan hasil-hasil yang dicapai oleh siswa sebagai peserta didik, dan juga memberikan membentuk watak dan kepribadian para siswa tersebut (Rooijakers.2000: 6).

Kebaruan dari penelitian ini yaitu dimana metode kooperatif tipe talking chips ini masih banyak guru di SMP belum menerapkannya. Artinya penelitian ini merupakan suatu pembaruan metode untuk mengajar siswa dengan meningkatkan kedisiplinan dan keaktifan siswa di dalam kelas.

\section{METODE PENELITIAN}

Metode penelitian adalah strategi umum yang menganut pengumpulan data dan analisis yang diperlukan, dengan menghadapi persoalan ini, berarti metode penelitian merupakan suatu masalah yang berdasarkan faktor empiris dan objektif untuk diuji secara ilmiah oleh siapapun. Metode yang digunakan dalam suatu penelitian ditentukan oleh sifat persoalan dan jenis data yang diperlukan. Oleh karena itu, dalam memilih metode penelitian hendaknya harus dapat dan sesuai dengan kebutuhan karena berhasil tidaknya penelitian tergantung pada sesuai tidaknya memilih dan menerapkan metode penelitiannya.

Penelitian ini menggunakan metode kualitatif yang dapat diartikan sebagi prosedur penulisan yang menghasilkan data deskriptif kata-kata tertulis atau lisan dari perilaku orang-orang yang diamati untuk menerapkan Metode Kooperatif Tipe Talking Chips kepada siswa. Sedangkan karya ilmiah ini bersifat deskriptif, yaitu 
memberikan gambaran suatu keadaan tertentu secara rinci disertai dengan bukti.

Tempat dan waktu pelaksaan penelitian bertempat di SMP Negeri 2 Sukowono, sedangkan waktu penelitian dilaksanakan pada tanggal 27 oktober 2018. Penelitian ini dikatakan penelitian populasi, karena penelitian populasi adalah keseluruhan objek penelitian. Apabila seseorang ingin meneliti semua elemen yang ada dalam wilayah penelitian, maka penelitiannya merupakan penelitian populasi. Sesuai dengan permasalah untuk menemukan jawaban apakah metode ini berhasil di terapkan pada siswa. Maka penelitian ini mengambil populasi dari kelas VII-E. Pada penelitian ini peneliti mengambil sampel sebanyak siswa dari kelas VII-E SMP Negeri 2 Sukowono. Dimana sumber data yang digunakan adalah sumber data primer yaitu yang diperoleh dari hasil angket/lembar pengisian soal.

Metode pengumpulan data yang digunakan untuk menyusun karya ilmiah ini adalah dengan metode angket. Angket merupakan lembaran yang berisi soal-soal serta bersangkutan dengan dengan masalah yang diteliti apakah dengan adanya metode ini siswa lebih disiplin dan mudah untuk berbicara didalam kelas untuk siswa yang kurang aktif.

Metode yang diterappan yaitu model pembelajaran kooperatif tife Talking Chips, yaitu 1. a match (mencari pasangan) dimana guru memberikan nama-nama anggota kelompok yang sebelumnya sudah disiapkan, 2. Think-Fair-Share (berpikir berpasangan - berbagi) setiap kelompok saling berfikir dengan cara jika kelompok 1 terdiri dari 3 orang makan diberi 3 soal dengan ketentuan 1 soal 1 siswa, 3. Time (Waktu) dimana siswa diberi waktu diskusi 3 menit, 4. talkingchips (kartu berbicara) setelah waktu habis maka guru memberikan sebuah 3 buah kartu per kelompok sebagai tiket untuk bertanya, menyanggah atau menambah jawaban., 4. roundtable (meja bundar) semua nggota menunjuk perwakilan kelompok untuk duduk di meja bundar. Dimana dengan adanya metode ini siswa wajib bertanya, meyangga atau menambahkan. Sehingga siswa yang tidak aktif akan lebih berani untuk berbicara. Terkait kedisiplinan siswa nantinya akan lebih mendengarkan guru yang memberi perintah atau lebih menghargai orang yang ada di depan.

\section{HASIL DAN PEMBAHASAN}

1. Data Siswa Kelas VII-E

\begin{tabular}{|l|l|l|}
\hline Nama & Kelas & Tempat, Tanggal Lahir \\
\hline Fitriana & VII-E & Jember, 27 Oktober 2005 \\
\hline Siti Alfina Riskiana & VII-E & Jember, 25 Juni 2006 \\
\hline Siti Istianatul Hotijah & VII-E & Jember, 12 Desember 2005 \\
\hline Erika Norma Salsabila & VII-E & Jember, 20 Desember 2006 \\
\hline Siti Amalia Fajaryanti & VII-E & Jember, 03 Maret 2005 \\
\hline Ibra Al Ayyubi Ilyas & VII-E & Jember, 01 Juni 2005 \\
\hline Irfan Fathoni & VII-E & Jember, 22 Mei 2006 \\
\hline Rifki Yanto & VII-E & Jember, 13 September 2005 \\
\hline Andika Wiro Atmaja & VII-E & Jember, 12 Agustus 2006 \\
\hline Muhammad Sholeh & VII-E & Jember, 06 September \\
\hline Mochammad Saiful Fajri & VII-E & Jember, 18 Februari 2004 \\
\hline Mulyanto & VII-E & Jember, 14 Desember 2004 \\
\hline Gracesha Shafania Syawal & VII-E & Jember, 20 November 2005 \\
\hline Nathania Tri Saskia & VII-E & Jember, 30 Desember 2005 \\
\hline Raisya Masywa Sabilillah & VII-E & Jember, 02 Maret 2006 \\
\hline M. Fajar Kurniawan & VII-E & Jember, 18 Mei 2005 \\
\hline M. Nafis Atoillah & VII-E & Jember, 25 Desember 2004 \\
\hline Tri Yahya Affandi & VII-E & Jember, 19 Mei 2005 \\
\hline
\end{tabular}

Eduscience Vol. I. No. 1 Desember 2018 


\begin{tabular}{|l|l|l|}
\hline Aris Bagas Rivaldi & VII-E & Jember, 13 Mei 2005 \\
\hline Rifaldo & VII-E & Jember, 10 April 2006 \\
\hline Serly Wulandari & VII-E & Jember, 05 Mei 2005 \\
\hline Jefri Yudi Maskuri & VII-E & Jember, 15 Januari 2004 \\
\hline Muhammad Zul Kifli & VII-E & Jember, 01 Juli 2006 \\
\hline Yuli Antika Putri & VII-E & Jember, 4 Januari 2006 \\
\hline Amelia Agustin & VII-E & Jember, 02 Agustus 2005 \\
\hline Andi April Yanto & VII-E & Jember, 3 April 2004 \\
\hline Nenik Agustin Nabila & VII-E & Jember, 29 Oktober 2004 \\
\hline Siti Romlah & VII-E & Jember, 18 April 2006 \\
\hline Nurul Aini & VII-E & Jember, 01 Maret 2006 \\
\hline
\end{tabular}

Hasil penelitian dengan angket/lembar pengisian soal dari sampel sebanyak 29 siswa kelas VII-E SMP Negeri 2 Sukowono, penelitian berhasil mengumpulkan data dibawah ini:

A. Apakah di dalam kelas selalu ramai: dari hasil penelitian $90 \%$ siswa menjawab tidak atau 26 siswa menjawab tidak, jadi sisanya yaitu $10 \%$ atau 3 siswa menjawab iya.

B. Apakah kamu selalu mendengarkan guru pada saat menjelaskan di depan: dari hasil penelitian $100 \%$ dari 29 siswa menjawab iya.

C. Apakah saat adanya interaksi antar kelompok atau pada saat guru menjelaskan didepan anda selalu bertanya, menyangga atau menambahkan jawaban : dari hasil penelitian $86 \%$ siswa atau 24 siswa menjawa iya, sisanya sebanyak $14 \%$ atau 5 siswa menjawab tidak.

\begin{tabular}{|l|l|l|}
\hline Pertanyaan & Iya & Tidak \\
\hline Apakah di dalam kelas selalu ramai ? & $10 \%$ & $90 \%$ \\
\hline $\begin{array}{l}\text { Apakah kamu selalu mendengarkan guru pada saat menjelaskan di depan } \\
?\end{array}$ & $100 \%$ & $0 \%$ \\
\hline $\begin{array}{l}\text { Apakah saat adanya interaksi antar kelompok atau pada saat guru } \\
\text { menjelaskan didepan anda selalu bertanya, menyangga atau } \\
\text { menambahkan jawaban? }\end{array}$ & $86 \%$ & $14 \%$ \\
\hline
\end{tabular}

Dengan melihat jawaban siswa yang seperti data di atas, maka peneliti menyimpulkan bahwa siswa sudah disiplin menurut angket yang siswa isi, akan tetap pada kenyataannya di dalam kelas tersebut masih terlihat siswa yang kurang disipin, dilihat pada saat peneliti memberikan materi masih terlihat banyak yang belum memperhatikan atau mengobrol sendiri dibelakang. Oleh karena itu, peneliti melihat angket yang tidak sesuai dengan kenyataan maka peneliti masih tetap menerapkan metode Kooperatif Tipe Talking Chips kepada siswa kelas VIII-E dengan langkahlangkahnya sebagai berikut:

1. a match (mencari pasangan) dimana guru memberikan nama-nama anggota kelompok yang sebelumnya sudah disiapkan, 2. Think-Fair-Share (berpikir - berpasangan - berbagi) setiap kelompok saling berfikir dengan cara jika kelompok 1 terdiri dari 3 orang makan diberi 3 soal dengan ketentuan 1 soal 1 siswa, 3. Time (Waktu) dimana siswa diberi waktu diskusi 3 menit, 4. talkingchips (kartu berbicara) setelah waktu habis maka guru memberikan 3 buah kartu per kelompok sebagai tiket untuk bertanya, menyanggah atau menambah jawaban., 4. roundtable (meja bundar) semua nggota menunjuk perwakilan kelompok untuk duduk di meja bundar. Jadi pada setiap pertemuan tatap muka maka setiap perwakilan kelompok ada satu anggota yang duduk dimeja bundar secara bergantian untuk minggu selanjutnya. Sampai semua anggota maju. Dimana dengan adanya metode ini siswa wajib bertanya, meyangga atau menambahkan. 
Sehingga siswa yang tidak aktif akan lebih berani untuk berbicara. Terkait kedisiplinan siswa nantinya akan lebih mendengarkan guru yang memberi perintah atau lebih menghargai orang yang ada di depan.

Peneliti hanya melihat 1 pertemuan saja dari hasil pertemuan tersebut dengan mengisi kelas yang kemudian menjelaskan sedikit materi, setelah selelsai peneliti memberikan sebuah angket/ lembar pengisian soal setelah metode kooperatif tipe talking chips diterapkan, adapun jawaban siswa sebagai berikut:

A. Dengan adanya metode ini apakah kelas sedikit lebih tenang dari sebelumnya: dari hasil penelitian $86 \%$ siswa menjawab iya atau 24 siswa dari 29 siswa, selebihnya yaitu 5 siswa menjawab tidak.

B. Dengan adannya metode pembelajaran seperti ini apakah kalian merasa lebih aktif: dari hasil penelitian 100\% siswa menjawab iya.

C. Dengan adanya metode ini apakah kalian merasa lebih memperhatiakn orang yang ngomong di depan: dari hasil penelitian 98\% siswa atau 28 siswa dari 29 siswa menjawab iya. Sisanya satu siswa menjawab tidak.

\begin{tabular}{|l|l|l|}
\hline Pertanyaan & Iya & Tidak \\
\hline $\begin{array}{l}\text { Dengan adanya metode ini apakah kelas sedikit lebih tenang dari } \\
\text { sebelumnya? }\end{array}$ & $86 \%$ & $14 \%$ \\
\hline $\begin{array}{l}\text { Dengan adannya metode pembelajaran seperti ini apakah kalian merasa lebih } \\
\text { aktif? }\end{array}$ & $100 \%$ & $0 \%$ \\
\hline $\begin{array}{l}\text { Dengan adanya metode ini apakah kalian merasa lebih memperhatikan orang } \\
\text { yang bicara di depan? }\end{array}$ & $98 \%$ & $2 \%$ \\
\hline
\end{tabular}

Dengan melihat angket yang merupakan jawaban dari siswa makan dapat dikatakan metode ini berhasil untuk meningkatkan siswa yang cenderung kurang aktif.

keunggulan yang diperoleh model pembelajaran Talking Chips yaitu:

a. Saling ketergantungan yang positif

b. Adanya pengakuan dalam merespon perbedaan individu

c. Siswa dilibatkan dalam perencanaan dan pengelolaan kelas

d. Suasana kelas yang rileks dan menyenangkan

e. Terjalin hubungan yang hangat dan bersahabat antara siswa dsan guru

f. Memiliki banyak kesempatan untuk mengekspresikan pengalaman emosi yang menyenangkan.

Sedangkan kelemahan dalam model pembelajaran Talking Chips diantaranya:

1. Tidak semua konsep dapat mengungkapkan model Talking Chips, disinilah tingkat profesionalitas seorang guru dap dinilai. Seorang guru yang profesional tentu dapat memilih metode dan model pembelajaran yang sesuai dengan materi yang akan dibahas dalam proses pembelajaran.

2. Pengelolaan waktu saat persiapan dan pelaksanaan perlu diperhatikan untuk meningkatkan kualitas pembelajaran, terutama dalam proses pembentukan pengetahuan siswa.

3. Pembelajaran model Talking Chips adalah model pembelajaran yang menarik namun cukup sulit dalam pelaksanaannya, karena memerlukan persiapan yang cukup sulit. Selain itu dalam pelaksanaannya guru dituntut untuk dapat mengawasi setiap siswa yang ada di kelas. Hal ini cukup sulit dilakukan terutama jika jumlah siswa dalam kelas terlalu banyak.

Langkah-langkah Model Pembelajaran Kooperatif Talking Chips Langkah-langkah model pembelajaran kooperatif talking chips menurut Widyantini (2008:6) adalah sebagai berikut: Menyampaikan tujuan dan motivasi siswa. 
Guru menyampaikan tujuan pembelajaran dan mengkouminaksikan kompetensi dasar yang akan dicapai serta memotivasi siswa.

1. Menyajikan informasi. Guru menyajikan informasi kepada siswa.

2. Mengkoordinasikan siswa kedalam kelompok-kelompok belajar. Guru mengelompokan siswa.

3. Membimbing kelompok belajar. Guru memfasilitasi kerja siswa untuk materi pembelajaran kelompok-kelompok belajar.

4. Evalusasi. Guru mengevaluasi hasil belajar tentang materi yang telah disampaikan.

5. Memberi penghargaan. Guru memberi penghargaan hasil belajar individu dan kelompok.

Talking chips mempunyai dua proses yang penting, yaitu: proses sosial dan proses dalam penguasaan materi. Proses sosial berperan penting dalam talking chips yang menuntut siswa untuk dapat bekerjasama dalam kelompoknya, sehingga para siswa dapat membangun pengetahuan mereka didalam lingkungan kelompoknya. Para siswa belajar untuk berdiskusi, meringkas, memperjelas suatu gagasan, dan konsep materi yang mereka pelajari, serta dapat memecahkan masalah-masalah. Talking Chips mempunyai tujuan tidak hanya sekedar penguasaan bahan pelajaran, tetapi adanya unsur kerjasama untuk penguasaan materi tersebut. Hal ini menjadi ciri khas dalam pembelajaran kooperatif. Disamping itu, talking chips merupakan metode pembelajaran secara kelompok, maka kelompok merupakan tempat untuk mencapai tujuan pembelajaran sehingga kelompok harus mampu membuat siswa untuk belajar.

Dengan demikian semua anggota kelompok harus saling membantu untuk mencapai tujuan pembelajaran. Selain dengan kelompoknya, siswa juga dapat berinteraksi dengan anggota kelompok lain sehingga tercipta kondisi saling ketergantungan positif didalam kelas mereka pada waktu yang sama. Proses penguasaan materi berjalan karena para siswa dituntut untuk dapat menguasai materi.

Dengan adanya metode seperti ini makan akan terlihat siswa yang berkarakkter baik artinya dengan metode ini siswa diberi kesempatan untuk wajib bertanya menyangga, menambah jawaban, sehingga tidak ada lagi siswa yang malu untuk berpendapat males, atau tidak pernah aktif di dalam kelas

Mengaplikasikan metode kooperatif tipe talking chips dalam pendidikan karakter siswa smp untuk mengingkatkan kedisiplinan siswa SMP, metode kooperati peserta didik belajar bersama-sama dalam kelompok kecil di dalam kelas berlangsung suatu pembelajaran dan membuat suatu data keolompok kecil dimana antara anak yang kurang aktif akan pertama dipaksa untuk menghabiskan kartu dimnana kartu tersebut sebagai tiket untuk bertanya, menyangga atau menambahakan suatu jawaban.

\section{SIMPULAN}

Jadi untuk menyelesaikan suatu permasalahn dimana siswa SMP di indonesia dalam pembelajaran kooperatif masih sengat rendah, maka guru perlu melaksanakan suatu metode kooperatif tipe talking chips untuk meningkatkan kedisiplinan dan keaktifan semua siswa SMP di dalam kelas.

\section{DAFTAR PUSTAKA}

Departemen Pendidikan Nasional. 2008. Kamus Besar Bahasa Indonesia. Jakarta: PT. Gramedia Pustaka Utama.

Aqila S. \& Sujak. 2011. Panduan dan Aplikasi Pendidikan Berkarakter. Bandung: Yram Widya.

Rooijakers. A.D. 2000. Mengajar Dengan Sukses. Jakarta: PT. Grasindo

Djamarah.S.B. 2000. Guru dan Anak Didik dalam Interakif Edukatif. Jakarta: Rineka Cipta.

Bassham \& Gregory .2011. Critical thinking a student's introduction. New York: McGraw-Hill Companies

Sudjana, N.2002. Dasar-dasar Proses Belajar Mengajar. Bandung: Sinar Baru Algesindo. 
DEPDIKNAS, .2006. UU RI No.20 Tahun 2003 Tentang Sistem Pendidikan Nasional. Jakarta: DEPDIKNAS

Enteng, K.2013. Penerapan Model Kooperatif Tipe Kancing Gemerincing Menggunakan Media Gambar Untuk Meningkatkan Menulis Cerita Rumpang. jurnal Antologi PGSD Bumi Siliwangi. Vol. I hal. 9. 